\title{
The Protein Polymorphism of Haptoglobin in Korean Elite Athletes
}

\author{
Byung Yong Kang ${ }^{a}$ Chin Yang Kang ${ }^{b}$ Sang Duk Oh ${ }^{c}$ Joon Seol Bae \\ Ki Tae Kim ${ }^{d}$ Kang Oh Lee ${ }^{e}$ \\ ${ }^{a}$ Research Institute for Life Science, Sahmyook University, bDepartment of Pharmacy, Sahmyook University, \\ 'College of Physical Education, Hanyang University, dSeoulin Bioscience Institute (SLBI), \\ Seoulin Bioscience, Co., Ltd, and e Department of Life Science, Sahmyook University, Seoul, Korea
}

\section{Key Words}

Endurance $\cdot$ Genotype and haptoglobin · Korean male athletes

\begin{abstract}
Objective: To investigate protein polymorphism of the haptoglobin ( $\mathrm{Hp}$ ) and the relationship between $\mathrm{Hp}$ phenotypes and anthropometric or biochemical parameters in elite Korean male athletes. Materials and Methods: Serum samples were collected from 120 Korean male elite athletes. The Hp phenotypes were determined by polyacrylamide gel electrophoresis, followed by peroxidase staining. Then anthropometric or biochemical measurements were made: body composition, blood pressures, ventilatory responses, cholesterol (total, LDL cholesterol and HDL cholesterol), triglyceride, apolipoprotein A1, lipoprotein (a), creatine phosphokinase and lactate dehydrogenase. Results: The gene frequencies of the Hp1-1, Hp2-1 and Hp2-2 phenotypes in Korean male athletes were 12, 37 and $51 \%$, respectively; this polymorphism was significantly associated with the $\mathrm{VO}_{2 \max }$ index in the athletes. An excess of the Hp1 allele was also observed in marathon runners compared with the other sporting activities, although it did not have any statistical significance. Conclusion: Hp polymorphism exists in
\end{abstract}

elite Korean male athletes and Hp phenotype may be a useful marker for endurance performance in these male athletes.

Copyright $\odot 2003$ S. Karger AG, Basel

\section{Introduction}

Cardiovascular function is an important element of athletic performance. A number of studies have suggested that many genes contribute to this function $[1,2]$ and that several causative genes contribute to the genetic make-up of athletic performance [3-5]. One such candidate gene is the haptoglobin $(\mathrm{Hp})$ [2]. Hp is one of the serum proteins that shows genetic polymorphism [6], and it functions as a hemoglobin-binding protein [7] or acute-phase protein [8]. In addition, it has many other properties [9]. Hp protein polymorphism manifests in three phenotypes: Hp1-1, Hp2-1 and Hp2-2, as shown by polyacrylamide gel electrophoresis. The synthesis of this protein is controlled by a single gene located on chromosome 16 [10]. Hp polymorphism is known to be associated with various cardiovascular diseases [11-15] or immune diseases [16-19]. However, to our knowledge, there is no report on the relationship between $\mathrm{Hp}$ polymorphism and athletic performance.

\section{KARGER \\ Fax +4161306 1234 \\ E-Mail karger@karger.ch \\ www.karger.com

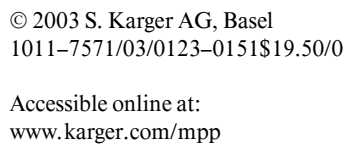

Dr. Kang Oh Lee
Department of Life Science, Sahmyook University
San 26-21, Kongreung-2Dong, Nowon-Gu
Seoul 139-742 (Korea)
Tel. +82 23399 3561, Fax +82 2971 6811, E-Mail leeko@syu.ac.kr 
In this study, the distribution of the Hp phenotypes was investigated among elite Korean male athletes. In addition, the relationship between $\mathrm{Hp}$ phenotypes and anthropometric or biochemical parameters of athletic groups was explored.

\section{Subjects and Methods}

\section{Subjects}

A total of 120 male elite athletes [15 basketball, 25 football, 32 baseball and 18 volleyball players, 12 gymnasts, 9 judo practitioners, 5 marathon and 4 middle-distant $(\geq 5,000 \mathrm{~m})$ runners] were randomly selected from the students of the Department of Physical Education, Hanyang University, Seoul, Korea.

\section{Determination of Anthropometric and Biochemical Parameters}

Blood samples were obtained in EDTA tubes from the subjects who had been fasting for 12-16 h. A sphygmomanometer was used to measure systolic and diastolic blood pressures (SBP and DBP, respectively). The mean arterial pressure was calculated by DBP $1 / 3$ (SBP - DBP) (mm Hg). The $\mathrm{VO}_{2 \max }$ index was measured by using motor-driven treadmills [20]. The body mass index value was calculated dividing the body weight $(\mathrm{kg})$ by the square of the height $\left(\mathrm{m}^{2}\right)$. Concentration of total cholesterol and triglyceride was measured by enzymatic colorimetric methods with a commercial kit (Boehringer Mannheim, Germany) and chemistry analyzer. High-density lipoprotein cholesterol was determined by measuring cholesterol in the supernatant after precipitation of the serum with $\mathrm{MgCl}_{2}$ and dextran sulfate, with a Gilford Impact 400E automated analyzer with reagents and calibrators from Boehringer Mannheim. Lipoprotein(a) level was measured by the immunoprecipitation method (SPQ Test System, Incstar Corporation, Stillwater, Minn., USA) and apolipoprotein A1 concentration was determined by the immunoturbidimetric method (Cobas Integra, Roche Diagnostics, USA). Low-density lipoprotein cholesterol level was calculated using the formula by Friedewald et al. [21]. Serum lactate dehydrogenase and creatine phosphokinase activity were measured by ultraviolet assay.

\section{Hp Phenotyping}

Hp phenotypes were determined by polyacrylamide gel electrophoresis and peroxidase staining with benzidine as previously described [22]. Briefly polyacrylamide gel was prepared with Peacock's gel buffer ( $\mathrm{pH}$ 8.29). The composition of electrode buffer was $0.089 M$ of tris(hydroxymethyl)aminomethane, $0.0025 M$ of EDTA, and $0.091 M$ of boric acid (pH 8.29). Electrophoresis was carried out at $200 \mathrm{~V}$ for $30 \mathrm{~min}$. The sampling mixture contained $50 \mu \mathrm{l} \mathrm{serum}$, $5 \mu \mathrm{l}$ blood hemolysate, and a little crystal sucrose. Staining of the gel was performed by adding the following mixture: $60 \mathrm{mg}$ of benzidine, $2 \mathrm{ml}$ of glacial acetic acid, $2 \mathrm{ml}$ of dimethyl sulfoxide, $2 \mathrm{ml}$ of $\mathrm{H}_{2} \mathrm{O}_{2}$ and $600 \mathrm{ml}$ of distilled water.

\section{Statistical Analysis}

Allele frequencies were estimated by the gene counting method. Deviation in genotype distribution from that expected for the HardyWeinberg equilibrium was estimated by the $\chi^{2}$ fitness test. The significance of differences in allele frequencies between populations was also estimated by the $\chi^{2}$ independence test. The comparisons of the $\begin{array}{llllllllll}1 & 2 & 3 & 4 & 5 & 6 & 7 & 8 & 9 & 10\end{array}$

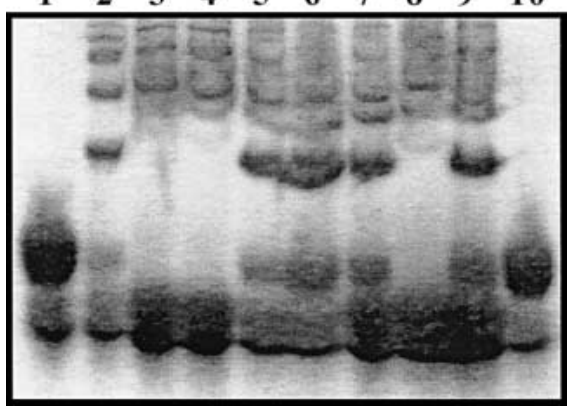

Fig. 1. Polymorphic patterns of the Hp. Lanes 1 and 10: Hp1-1 genotypes; lanes 2, 5-7 and 9: Hp2-1 genotypes; lanes 3, 4 and 8: Hp2-2 genotypes.

variables across the phenotypes were performed by using a parametric one-way ANOVA test with Scheffe's multiple comparison test. Statistical significance was set at $p=0.01$. All statistical analyses were performed by the computer program of Statistica (version 6.0).

\section{Results}

\section{Phenotype Distribution}

The polymorphic patterns of $\mathrm{Hp}$ in the Korean male athletes are shown in figure 1 and the gene frequencies in table 1. The frequencies of the Hp1-1, Hp2-1 and Hp2-2 phenotypes were 12,37 and $51 \%$, respectively. The observed phenotype distribution did not significantly deviate from the Hardy-Weinberg equilibrium. Derived allele frequencies for $\mathrm{Hp} 1$ and $\mathrm{Hp} 2$ were 0.31 and $0.69 \%$, respectively. Among the 8 different athletic groups, the highest excess of the Hp1 allele was observed in marathon runners, although this was not statistically significant.

\section{Association with Biochemical Parameters}

Table 2 presents the comparison of anthropometric data and intermediate phenotypes across Hp polymorphism in male elite athletes. There were significant differences in the $\mathrm{VO}_{2 \max }$ index across the phenotypes (one-way ANOVA test, $p=0.008)$. Hp1-1 homozygotes (57.0 \pm 1.3 $\mathrm{ml} / \mathrm{kg} / \mathrm{min}$ ) had significantly higher values for the $\mathrm{VO}_{2 \max }$ index than Hp2-2 homozygotes $(55.4 \pm 1.7 \mathrm{ml} / \mathrm{kg} / \mathrm{min}$; Scheffe's multiple comparison, $\mathrm{p}=0.008)$, but marginally higher than Hp2-1 heterozygotes $(55.7 \pm 1.3 \mathrm{ml} / \mathrm{kg} / \mathrm{min}$; Scheffe's multiple comparison, $\mathrm{p}=0.052)$. However, 
Table 1. Distribution of $\mathrm{Hp}$ protein polymorphism in the Korean male elite athletic groups

\begin{tabular}{|c|c|c|c|c|c|}
\hline \multirow[t]{3}{*}{ Subjects } & \multicolumn{5}{|c|}{ Haptoglobin } \\
\hline & \multicolumn{3}{|c|}{ phenotypes } & \multicolumn{2}{|l|}{ alleles } \\
\hline & Hp1-1 & Hp2-1 & Hp2-2 & Hp1 & $\mathrm{Hp} 2$ \\
\hline Basketball $(n=15)$ & $1(7)$ & $3(20)$ & $11(73)$ & $5(17)$ & $25(83)$ \\
\hline Soccer $(n=25)$ & $3(12)$ & $9(36)$ & $13(52)$ & $15(30)$ & $35(70)$ \\
\hline Baseball $(n=32)$ & $3(9)$ & $14(44)$ & $15(47)$ & $20(31)$ & $44(69)$ \\
\hline Gymnastics $(\mathrm{n}=12)$ & $3(25)$ & $3(25)$ & $6(50)$ & $9(38)$ & $15(62)$ \\
\hline Volleyball $(\mathrm{n}=18)$ & $4(22)$ & $6(33)$ & $8(45)$ & $14(39)$ & $22(61)$ \\
\hline $\operatorname{Runner}^{1}(\mathrm{n}=4)$ & $0(0)$ & $2(50)$ & $2(50)$ & $2(25)$ & $6(75)$ \\
\hline Judo $(n=9)$ & $0(0)$ & $4(44)$ & $5(56)$ & $4(22)$ & $14(78)$ \\
\hline Marathon $(n=5)$ & $1(20)$ & $3(60)$ & $1(20)$ & $5(50)$ & $5(50)$ \\
\hline Total $(\mathrm{n}=120)$ & $15(12)$ & $44(37)$ & $61(51)$ & $74(31)$ & $166(69)$ \\
\hline
\end{tabular}

\begin{tabular}{|c|c|c|c|c|}
\hline \multirow[t]{2}{*}{ Variables } & \multicolumn{4}{|c|}{ Phenotypes } \\
\hline & Hp1-1 & & Нp2-1 & Hp2-2 \\
\hline Age, year & $19.9 \pm$ & $1.1(11)$ & $1.2(35)$ & $20.4 \pm$ \\
\hline BMI $\left(\mathrm{kg} / \mathrm{m}^{2}\right)$ & $21.6 \pm$ & $1.7(12)$ & $1.6(35)$ & $2.1(49)$ \\
\hline $\mathrm{VO}_{2 \max }{ }^{\mathrm{a}}, \mathrm{ml} / \mathrm{kg} / \mathrm{min}$ & $57.0 \pm$ & $1.3(12)$ & $1.3(35)$ & $1.7(49)$ \\
\hline $\mathrm{SBP}, \mathrm{mm} \mathrm{Hg}$ & $117.6 \pm$ & $8.1(12)$ & $8.1(36)$ & $118.7 \pm$ \\
\hline DBP, mm Hg & $69.3 \pm$ & $8.4(12)$ & $7.5(36)$ & $6.4(51)$ \\
\hline MAP, mm Hg & $85.3 \pm$ & $7.1(12)$ & $88.3 \pm 6.8(36)$ & $88.0 \pm 5.9(51)$ \\
\hline $\mathrm{Tg}, \mathrm{mg} / \mathrm{dl}$ & $92.9 \pm$ & $53.3(15)$ & $108.0 \pm 83.2(44)$ & $102.9 \pm 62.7(61)$ \\
\hline $\mathrm{TC}, \mathrm{mg} / \mathrm{dl}$ & $161.4 \pm$ & $23.4(15)$ & $169.6 \pm 27.4(44)$ & $179.8 \pm 46.8(61)$ \\
\hline LDL-chol, mg/dl & $78.2 \pm$ & $33.1(15)$ & $87.8 \pm 28.7(44)$ & $100.2 \pm 47.6(61)$ \\
\hline HDL-chol, mg/dl & $57.7 \pm$ & $12.6(15)$ & $58.6 \pm 12.6(44)$ & $57.5 \pm 12.2(61)$ \\
\hline $\mathrm{Lp}(\mathrm{a}), \mathrm{mg} / \mathrm{dl}$ & $13.0 \pm$ & $18.0(6)$ & $7.2 \pm \quad 4.3(22)$ & $8.2 \pm \quad 7.7(32)$ \\
\hline Apo, mg/dl & $88.4 \pm$ & $20.3(15)$ & $111.0 \pm 33.2(44)$ & $102.4 \pm 33.8(61)$ \\
\hline CPK, IU/1 & $794.9 \pm 1,3$ & $332.9(15)$ & $625.0 \pm 873.0(43)$ & $412.0 \pm 639.3(61)$ \\
\hline LDH, IU/1 & $486.7 \pm$ & $139.7(15)$ & $457.1 \pm 99.0(44)$ & $449.8 \pm 89.4(61)$ \\
\hline
\end{tabular}

$\mathrm{BMI}=$ Body mass index; $\mathrm{MAP}=$ mean arterial pressure $; \mathrm{Tg}=$ triglyceride $; \mathrm{TC}=$ total cholesterol; LDL-chol $=$ LDL cholesterol; HDL-chol $=$ HDL cholesterol; Lp(a) $=$ lipoprotein(a); ApoA1 = apolipoprotein A1; $\mathrm{CPK}=$ creatine phosphokinase; $\mathrm{LDH}=$ lactate dehydrogenase. Values are mean \pm SD. Figures in parentheses indicate number of subjects.

a Statistically significant difference (one-way ANOVA test, $\mathrm{p}=0.008$ ). there was no statistically significant difference between the Hp2-1 and Hp2-2 phenotypes (Scheffe's multiple comparison, $\mathrm{p}=0.645$ ). A recessive model on the $\mathrm{Hp} 1$ allele of the $\mathrm{VO}_{2 \max }$ index provides the best fit for our data, so the Hp1-1 phenotype might be considered a factor for endurance performance in our male athletic group. No association was found between Hp phenotypes and the other anthropometric or biochemical parameters.

\section{Discussion}

Many genetic and environmental factors contribute to athletic performance. Specific candidate genes have been tested for association with athletic performance [22-35], and recently, several genetic factors for this phenotype have been gradually elucidated. These include the I/D polymorphism of the angiotensin-I-converting enzyme 
gene $[22,25,26]$ and the Dra I RFLP of the $\alpha_{2 \mathrm{~A}}$-adrenergic receptor gene [32]. Nevertheless, the genetic variations responsible for athletic performance remain largely unknown [36], and the success to date in identifying causative genes has been very limited.

Delanghe et al. [37] reported that $\mathrm{Hp}$ polymorphism was associated with maximal walking distance in peripheral arterial occlusive disease patients with severe atherosclerotic lesions, but the role of Hp polymorphism in elite athletic groups has not been studied. The present study revealed that the $\mathrm{VO}_{2 \max }$ index is significantly associated with the Hp phenotype in elite Korean male athletes. However, if the Bonferroni correction is applied in 16 tests, our result is no longer significant with a $p$ value of $0.003(0.05 / 16)$. Nevertheless, it could be argued that the Bonferroni correction may give a low probability of detecting a small effect of the Hp phenotype, and eventually increase the possibility of type II error. This is why we cannot exclude the possibility that the $\mathrm{Hp}$ phenotype is somehow involved in the $\mathrm{VO}_{2 \max }$ index, although multiple comparisons such as these have the potential to generate spurious significances at the $p=0.01$ level for 1 in every 16 tests. Thus, our result awaits precise confirmation from a large-scale study.

When we examined phenotype and allele frequency of $\mathrm{Hp}$ according to each sporting event, there was an excess of the Hp1 allele in marathon runners compared with the other sporting events. This result may imply that the Hp phenotype accounts for a portion of the interindividual differences in athletic endurance performance. It is difficult to explain the mechanism for this association of the $\mathrm{Hp}$ phenotypes with endurance performance. However, a plausible explanation is the functional differences betwen Hp phenotypes. At present, multiple functional differences among these Hp phenotypes [9, 11-15] have been reported. The Hp1-1 phenotype may influence the athletic performance through mechanisms such as stronger hemoglobin-binding ability and antioxidative capacity compared with other phenotypes [9]. Also, Hp2-2 is associated with various cardiovascular diseases when compared with Hp1-1 phenotypes, suggesting a possible advantage for the Hp1-1 phenotype in cardiovascular function [11-15]. Another possibility is that the effect of the Hp phenotype on the interindividual difference in the $\mathrm{VO}_{2 \max }$ index results from linkage disequilibrium between the Hp phenotype and another causative allele. Some studies have suggested linkage disequilibrium as a mechanism for the association between the Hp phenotype and serum lipid levels [38-40].

This study is the first report of an association between endurance performance and $\mathrm{Hp}$ polymorphism in an elite athletic group. Thus, our study may help clarify the genetic basis for endurance performance, and provide a basis for further investigation. It is, however, premature to draw any firm conclusions about the genetic basis of endurance performance in elite Korean athletes because of the relatively small number of subjects $(n=120)$, especially for middle-distance $(n=4)$ and marathon runners $(\mathrm{n}=5)$. These studies also need to be confirmed in elite athletes from other ethnic groups.

\section{Conclusion}

The results suggest that the distribution of Hp phenotypes in Korean male elite athletes is significantly associated with the $\mathrm{VO}_{2 \max }$ index and may be a useful marker for endurance performance in these elite Korean athletes.

\section{References}

1 Hagberg JM, Moore GE, Ferrel RE: Specific genetic markers of endurance performance and $\mathrm{VO}_{2 \max }$. Exerc Sport Sci Rev 2001;29:15-19.

2 Rankinen T, Perusse L, Rauramaa R, Rivera MA, Wolfarth B, Bouchard C: The human gene map for performance and health-related fitness phenotypes. Med Sci Sports Exerc 2001;33: 855-867.

3 Rankinen T, Wolfarth B, Simoneau J-A, Maire-Lenz D, Rauramaa R, Rivera MA, Boulay MR, Chagnon YC, Perusse L, Keul J, Bouchard $\mathrm{C}$ : No association between the angiotensin-converting enzyme ID polymorphism and elite endurance athlete status. J Appl Physiol 2000;88:1571-1575.
4 Rivera MA, Dionne FT, Simoneau JA, Perusse L, Chagnon M, Chagnon Y, Gagnon J, Leon AS, Rao DC, Skinner JS, Wilmore JH, Bouchard C: Muscle-specific creatine kinase gene polymorphism and $\mathrm{VO}_{2 \max }$ in the Heritage Family Study. Med Sci Sports Exerc 1997;29: 1311-1317.

5 Rivera MA, Perusse L, Simoneau JA, Gagnon J, Dionne FT, Leon AS, Skinner JS, Wilmore JH, Province M, Rao DC, Bouchard C: Linkage between a muscle-specific $\mathrm{CK}$ gene marker and $\mathrm{VO}_{2 \max }$ in the Heritage Family Study. Med Sci Sports Exerc 1999;31:698-701.
6 Smithies O: Zone electrophoresis in starch gels: Group variations in the serum proteins of normal human adults. Biochem J 1955;61:629641.

7 Giblett ER: The haptoglobin system. Ser Haematol 1968;1:3-20.

8 Raynes JG, Eagling S, McAdam KP: Acutephase protein synthesis in human hepatoma cells: Differential regulation of serum amyloid A (SAA) and haptoglobin by interleukin-1 and interleukin-6. Clin Exp Immunol 1991;83: 488-491. 
9 Lamglois MR, Delanghe JR: Biological and clinical significance of haptoglobin polymorphism in humans. Clin Chem 1996;42:15891600.

10 Cox DR, Gedde-Dahl T Jr: Report of the Committee on the Genetic Constitution of Chromosome 13,14, 15 and 16. Cytogenet Cell Genet 1985;40:206-241.

11 Chapelle JP, Albert A, Smeets JP, Heusghem C, Kulbertus HE: Effect of the haptoglobin phenotype on the size of a myocardial infarct. N Engl J Med 1982;307:457-463.

12 Delanghe JR, Duprez DA, Buyzere ML, Bergez BM, Callens BY, Leroux-Roels GG, Clement DL: Haptoglobin polymorphism and complications in established essential arterial hypertension. J Hypertens 1993;11:861-867.

13 Delanghe J, Duprez D, De Buyzere M, Bergez B, Claeys L, Leroux-Roels G, Clement D: Refractory hypertension is associated with haptoglobin 2-2 phenotype. J Cardiovasc Risk 1995; 2:131-136.

14 Fröhlander N, Johnson O: Haptoglobin groups in acute myocardial infarction. Hum Hered 1989;39:345-350.

15 Prabha PS, Padma T, Ramaswamy M: Haptoglobin patterns in essential hypertension and associated conditions - increased risk for $\mathrm{Hp} 2$ 2. Hum Hered 1987;37:345-348.

16 Beckman G, Beckman L, Cedergren B, Göransson $\mathrm{K}$, Liden $\mathrm{S}$ : Blood groups, serum groups and red cell enzyme types in allergic contact dermatitis. Hum Hered 1981;31:54-60.

17 Fröhlander N, Stjernberg N: Association between haptoglobin groups and hereditary predisposition for bronchial asthma. Hum Hered 1989;39:7-11

18 Rantapää Dahlqvist S, Fröhlander N: Haptoglobin groups and rheumatoid arthritis. Hum Hered 1985;35:207-211.

19 Rantapää Dahlqvist S, Beckman G, Beckman $\mathrm{L}$ : Serum protein markers in systemic lupus erythematosus. Hum Hered 1988;38:44-47.

20 Strømme JB, Inger F, Meen HD: Assessment of maximal aerobic power of specifically trained athletes. J Appl Physiol 1977;42:833-837.
21 Friedewald WT, Levy RI, Fredrickson DS: Estimation of the concentration of low-density lipoprotein cholesterol in plasma without the use of the preparative ultracentrifuge. Clin Chem 1972;18:499-502.

22 Alvarez R, Terrados N, Ortolano R, IglesiasCubero G, Reguero JR, Batalla A, Cortina A, Fernández-García $\mathrm{B}$, Rodríguez $\mathrm{C}$, Braga $\mathrm{S}$, Alvarez V, Coto E: Genetic variation in the renin-angiotensin system and athletic performance. Eur J Appl Physiol 2000;82:117-120.

23 Buemann B, Schierning B, Toubro S, Bibby BM, Sorensen T, Dalgaard L, Pederson O, Astrup A: The association between the val/ala-55 polymorphism of the uncoupling protein 2 gene and exercise efficiency. Int $\mathrm{J}$ Obes Relat Metab Disord 2001;25:467-471.

24 Dionne FT, Turcotte L, Thibault MC, Boulay MR, Skinner JS, Bouchard C: Mitochondrial DNA sequence polymorphism, $\mathrm{VO}_{2 \max }$, and response to endurance training. Med Sci Sports Exerc 1993;25:766-774.

25 Gayagay G, Yu B, Hambly B, Boston T, Hahn A, Celermajer DS, Trent RJ: Elite endurance athletes and the ACE I allele - the role of genes in athletic performance. Hum Genet 1998;103: $48-50$.

26 Hagberg JM, Ferrell RE, McCole SD, Wilund $\mathrm{KR}$, Moore GE: $\mathrm{VO}_{2 \max }$ is associated with ACE genotype in postmenopausal women. J Appl Physiol 1998;85:1842-1846.

27 Moore GE, Shuldiner AR, Zmuda JM, Ferrell RE, McCole SD, Hagberg JM: Obesity gene variant and elite endurance performance. Metabolism 2001;50:1391-1392.

28 Myerson S, Hemingway H, Budget R, Martin J, Humphries S, Montgomery H: Human angiotensin-I converting enzyme gene and endurance performance. J Appl Physiol 1999;87: 1313-1316.

29 Murakami H, Soma R, Hayashi JJ, Katsuta S, Matsuda M, Ajisaka R, Okada M, Kuno S: Relationship between mitochondrial DNA polymorphism and the individual differences in aerobic performance. Jpn J Physiol 2001;51: 563-568.

30 Nazarov IB, Woods DR, Montgomery HE, Shneider OV, Kazakov VI, Tomilin NV, Rogozkin VA: The angiotensin-converting enzyme I/D polymorphism in Russian athletes. Eur J Hum Genet 2001:9:797-801.
31 Rivera MA, Wolfarth B, Dionne FT, Chagnon M, Simoneau JA, Boulay MR, Song TM, Perusse L, Gagnon J, Leon AS, Rao DC, Skinner JS, Wilmore JH, Keul J, Bouchard C: Three mitochondrial DNA restriction polymorphisms in elite endurance athletes and sedentary controls. Med Sci Sports Exerc 1998;30: 687-690.

32 Wolfarth B, Rivera MA, Oppert JM, Boulay MR, Dionne FT, Chagnon M, Gagnon J, Chagnon Y, Perusse L, Keul J, Bouchard C: A polymorphism in the alpha2a-adrenoceptor gene and endurance athlete status. Med Sci Sports Exerc 2000;32:1709-1712.

33 Woods DR, Brull D, Montgomery HE: Endurance and the ACE I/D polymorphism. Sci Prog 2000;83:317-336.

34 Wood D, Hickman M, Jamshidi Y, Brull D, Vassiliou V, Jones A, Humphries S, Montgomery $\mathrm{H}$ : Elite swimmers and the D allele of the ACE I/D polymorphism. Hum Genet 2001; 108:230-232.

35 Ziman MR, Jeenah MS: The relation between the Pst I restriction fragment length polymorphism at the Apo-AI locus and plasma Apo-AI concentrations in marathon runners. $\mathrm{S}$ Afr Med J 1995;85:1013-1016.

36 Gagnon J, Ho-Kim MA, Chagnon YC, Perusse L, Dionne T, Leon AS, Rao DC, Skinner JS, Wilmore JH, Bouchard C: Absence of linkage between $\mathrm{VO}_{2 \max }$ and its response to training with markers spanning chromosome 22. Med Sci Sports Exerc 1997;29:1448-1453.

37 Delanghe J, Langlois M, Duprez D, Buyzere MD, Clement D: Haptoglobin polymorphism and peripheral occlusive disease. Atherosclerosis 1999;145:287-292.

38 Hong SH, Kang BY, Lim JH, Namkoong Y, Oh MY, Kim JQ, Lee CC: Haptoglobin polymorphism in Korean patients with cardiovascular diseases. Hum Hered 1997;47:283-287.

39 Børresen A-L, Leren T, Berg K, Solaas MH: Effect of haptoglobin subtypes on serum lipid levels. Hum Hered 1987;37:150-156.

40 Fröhlander N: Haptoglobin groups and serum cholesterol levels. Hum Hered 1987;37:323325 . 